\title{
GREEN SYNTHESIS OF SILVER NANOPARTICLES USING AQUEOUS EXTRACT OF HOT CHILI PEPPER FRUITS AND ITS ANTIMICROBIAL ACTIVITY AGAINST PSEUDOMONAS AERUGINOSA
}

\author{
O. E. SMIRNOV ${ }^{1,2}$, V. Ye. KALYNOVSKYI ${ }^{1}$, Yu. M. YUMYNA ${ }^{1}$, P. P. ZELENA ${ }^{1}$, \\ M. A. SKORYK ${ }^{3}$, V. M. DZHAGAN $N^{4}, N$. YU. TARAN ${ }^{1}$
}

\begin{abstract}
${ }^{1}$ ESC "Institute of Biology and Medicine", Taras Shevchenko National University of Kyiv, Ukraine;
${ }^{2}$ Institute of Plant Physiology and Genetics, National Academy of Sciences of Ukraine, Kyiv;

${ }^{3}$ G.V. Kurdyumov Institute for Metal Physics, National Academy of Sciences of Ukraine, Kyiv;

${ }^{4}$ V. Lashkaryov Institute of Semiconductors Physics, National Academy of Sciences of Ukraine, Kyiv; e-mail: plantaphys@gmail.com
\end{abstract}

Received: 09 April 2021; Accepted: 22 September 2021

Green synthesis of different nanoparticles using the plants aqueous extracts has several advantages over other methods due to the environmentally favorable nature of plants. Moreover, such approach is also cost effective. This work describes the biosynthesis of silver nanoparticles (Ag-NPs) with the use of the aqueous extract of dry pericarps of hot chili peppers (Capsicum sp. cv. Teja (S-17) and cv. Carolina Reaper) with different levels of pungency and their antibacterial effect on the antibiotic resistant Pseudomonas aeruginosa. Phytochemical screening of pericarp tissues showed great distinction in contents of phenolic compounds and capsaicinoids as potential reducing agents wich correlated with total antiradical activity as analyzed by reduction of DPPH radicals. The biosynthesized Ag-NPs were characterized by UV-vis spectrophotometry and scanning electron microscopy (SEM). The average size of the nanoparticles in both samples was less than $25 \mathrm{~nm}$. Initial concentration of both samples of Ag-NPs inhibited P. aeruginosa growth with equal efficiency.

Keywords: green synthesis, Ag nanoparticles, Capsicum sp., antibacterial activity.

$\mathrm{S}$ ilver nanoparticles (Ag-NPs) show remarkable physical, chemical and biological properties, which determine their extensive use in various fields of optics, electronics, materials science and nanomedicine. As metallic nanoparticles, Ag-NPs are widely applied in different drug-delivery systems, imaging probes and photothermal approaches in anti-tumor therapy. At the same time, Ag-NPs inherit widely known antimicrobial properties of silver, which leads to the use of silver-based nanomaterials in surgery instruments, prosthetic devices, wound dressings and antiseptics [1].

The importance of Ag-NPs becomes even more evident given their ability to effectively reduce viability and suppress growth of numerous pathogens. Uncontrolled use of antibiotics in both public healthcare and agriculture gives rise to versatile multi- drug resistant strains of bacteria like Staphylococcus aureus and Pseudomonas aeruginosa, which is a serious therapeutic issue even under the controlled conditions of medical facilities. At the same time, Ag-NPs were proved to have bactericidal effects disregarding the resistance of these organisms to antibiotics [2].

The increasing demand for Ag-NPs in both industry and medicine raises the question about effective and safe ways of nanoparticle synthesis. It is generally accepted that metallic nanoparticles can be obtained through laser ablation, chemical, thermal or photo reduction of various compounds and evaporation-condensation approach [3]. Still, different types of nanomaterials, including Ag-NPs can be manufactured through "green synthesis" approach, which is considered superior to the abovementioned 
techniques due to the simplicity and biosafety because of absence of hazardous materials and toxic intermediates $[4,5]$.

Plant-mediated green synthesis of Ag-NPs includes the reduction of $\mathrm{Ag}$ ions by natural agents that can be found in roots, leaves, bark, fruits, seeds and flowers of vatious species. These substances comprise the natural antioxidative defense system, which includes different plant metabolites: alkaloids, tannins, saponins, terpenoids, polyphenols and flavonoids [6]. The accumulation of these molecules is dedicated to their remarkable antioxidative activity, which is used by plants to protect from reactive oxygen species and other free radical species, that can be generated both thorough normal cellular metabolic processes and action of exogenous compounds [7].

The potentially effective system for green synthesis of Ag-NPs should be based on the plant that contains substantial amount of bioreducers and at the same time is relatively easy to cultivate. These requirements are met in case of peppers (Capsicum $s p$.), which are used as a spice due to their ability to store capsaicinoids, along with other antioxidants, like phenolic compounds, carotenoids and ascorbic acid. The long history of artificial selection of peppers resulted in forms that are able to accumulate huge amounts of reducers - a beneficial trait for any Ag-NP-producing system [8].

It has also been shown that properties of metallic nanoparticles depend not only on the exact composition of nanostructure, but also on the stabilizing agents, which cover surface of nanoparticles and prevent their adhesion [9]. In case of plant-mediated green synthesis, these stabilizers are the same reducers that produce Ag-NPs. Thus, plant-derived Ag-NPs, along with their antimicrobial properties, can impose defensive or antioxidant action on the cells of multicellular organisms $[6,10,11]$.

Aim of the study - assessment of total phenolic compounds and capsaicinoids content in Capsicum sp. cv. Teja (S-17) and cv. Carolina Reaper pericarp tissues, experimental optimization of operating parameters needed for biosynthesis of Capsicum $s p$. silver nanoparticles, the characterization and application of silver nanoparticles on antibiotic resistant Pseudomonas aeruginosa. The novelty of our study is in the comparative assessment of nanoparticleproducing capabilities of two different varieties of Capsicum sp., which can further be used to improve modern green synthesis approaches.

\section{Materials and Methods}

Chemicals. The extraction solvents and reagents were of p.a. grade purity: methanol, acetone, dipotassium phosphate (Fisher Chemicals, USA); 2,2-diphenyl-1-picrylhydrazyl (Sigma-Aldrich, Germany). Silver nitrate, Folin-Ciocalteu's phenol reagent, Gibb's reagent, standard gallic acid were purchased from Acros Organics (Belgium).

Plant material. Healthy and fresh fruits (pericarps) of Capsicum sp. cv. Teja (S-17) and cv. Carolina Reaper were washed several times in deionized water to remove the soil particles and then air dried at $60^{\circ} \mathrm{C}$ to eliminate the residual moisture.

Measurement of total phenolic compounds, capsaicinoids content and DPPH activity in extracts of pepper pericarps. Levels of total phenolic, total capsaicinoids and total antiradical activity in extracts were measured with spectrophotometer UV1800 (Shimadzu, Japan). Extraction with methanol and acetone was used to demonstrate the maximum potential of the content of organic reducing agents phenolic compounds and capsaicinoids.

Total phenolic content analysis was performed with Folin-Ciocalteu reagent by the method [12]. We used $80 \%$ methanol as a solvent and gallic acid as a standard to make a calibration curve. Results were expressed in mg of gallic acid equivalents (GAE) per $\mathrm{g}$ of dry weight (DW). Total capsaicinoids content analysis ( $80 \%$ acetone was used as a solvent) was estimated with Gibbs reagent (2,6-dichloroquinone4-chloroimide) by the method [13] with minor modifications. $50 \mathrm{mg}$ of dry pericarp tissues powder was transferred to a centrifuge tube with $5 \mathrm{ml}$ acetone for extraction at $50^{\circ} \mathrm{C}$ during $30 \mathrm{~min}$. Total capsaicinoids contents were calculated using the molar extinction coefficient of 2,6-dichlorophenol indophenol according to [14] and expressed in mg per $\mathrm{g}$ of DW. The concentrations of total capsaicinoids (TC) were converted into Scoville Heat Units (SHU) with the following formula (we used their coefficient of the heat value) [8]:

$$
\mathrm{SHU}=\mathrm{TC} \mu \mathrm{g} \times 16.1
$$

DPPH radical scavenging capacity assay was used to quantify the ability of reducing components of plant extracts to quench the DPPH radical. The dark purple color of DPPH will be lost when it is reduced to its nonradical form. The color of the reaction mixture changes from purple to yellow with decrease of absorbance at $517 \mathrm{~nm}$ wavelength. The percentage of inhibition was calculated against blank: 
DPPH inhibition\% $=\left(\mathrm{A}_{\text {blank }}-\mathrm{A}_{\text {sample }} / \mathrm{A}_{\text {blank }}\right) \times 100$, where Ablank is the absorbance of the control reaction, containing all reagents except the test extract and Asample is the absorbance of the test extract [15].

Preparation of aqueous fruit extract and biosynthesis of Ag nanoparticles. Dry pericarps with removed placenta were cut into small pieces and two grams of pericarp tissues were put in a flask with flat bottom with $100 \mathrm{ml}$ deionized water and boiled for $20 \mathrm{~min}$. The obtained extract was cooled at room temperature and filtered with Whatman No.1 filter paper. Silver nanoparticles were synthesized by Capsicum sp. filtered extract by addition of $0.001 \mathrm{M}$ silver nitrate [16]. For the reduction of silver ions, $10 \mathrm{ml}$ of fruit extract was mixed with $40 \mathrm{ml}$ of $\mathrm{AgNO}_{3}$. The resulting solution was incubated for two hours at room temperature for the development of silver nanoparticles under light-emitting diode lamp (Secret Jardin, 42 W, 6500 K).

Characterization of aqueous fruit extract and biosynthesized Ag nanoparticles. UV-vis spectra of obtained Ag-NP solutions and pericarp extracts were recorded with UV-1800 (Shimadzu, Japan) UV-vis spectrophotometer at resolution of $1 \mathrm{~nm}$. After dessication of the purified silver nanoparticles at $60^{\circ} \mathrm{C}$, the size distribution was estimated by scanning electron microscopy (SEM, Tescan Mira 3 MLU).

Antibacterial activity of aqueous fruit extract and biosynthesized Ag nanoparticles. The antimicrobial activity of test samples against common pathogenic microbe Pseudomonas aeruginosa was evaluated with agar diffusion test method [17]. The culture of the test bacteria was grown in nutrient broth (Himedia) and adjusted to 0.5 McFarland turbidity standards. $1 \mathrm{ml}$ of 24-hour Pseudomonas aeruginosa culture suspension was inoculated on the surface of solidified Mueller-Hinton agar in Petri plates. Then 5 wells per one plate were made in agar with cylindrical metal tube and $100 \mu \mathrm{l}$ aliquots of test samples were added to the wells. Commercially available single antibiotic disc impregnated with ceftriaxone CK30 (Himedia) were aseptically placed on the Mueller-Hinton agar plates as a control. Both the samples and the control were incubated at $37^{\circ} \mathrm{C}$ for 18-24 $\mathrm{h}$ and the diameters of zones of inhibition for six separate determinations were recorded.

Statistical analysis. Each experiment was performed in at least triplicate. The results were expressed as mean \pm standard deviation (SD). The analysis of variance (ANOVA) followed by Duncan's multiple range test was performed using STATISTICA (StatSoft, USA). A value of $P<0.01$ was considered significant.

\section{Results and Discussion}

The efficiency of capsaicinoids extraction from dried plant material by different solvents have previously showed that acetone-based extraction produces significantly greater amounts of total capsaicinoids, in contrary to methanol, which extracts total phenolic compounds more efficiently [18]. Furthermore, methanol as a solvent is more commonly used for determination of total antioxidant potential of plant extracts [19].

Total phenolic content in the investigated methanol extracts of Capsicum sp. dry pericarps varied from 9.88 (cv. Teja (S-17)) to 32.85 (cv. Carolina Reaper) mg GAE/g DW (Fig. 1, A). As illustrated in Fig. 1, $B$ acetone extracts of cv. Teja (S-17) fruits demonstrated 8-fold lower content of total capsaicinoids as compared to the extracts of $\mathrm{cv}$. Carolina Reaper fruits, produced with the same solvent -5.88 and $41.91 \mathrm{mg} / \mathrm{g}$ DW respectively.

Among capsaicinoid derivatives, capsaicin and dihydrocapsaicin account for $80-90 \%$ of the capsaicinoids in hot chili peppers and are therefore considered the main determinants of pungency [13]. Quantitative identification of total capsicinoids allows transformation of these values into in Scoville Heat Units (SHU), a widely used parameter, defined by the coefficient of the heat value, to demonstrate level of Capsicum sp. pungency. Acetone extracts from Carolina Reaper pericarp tissues showed the highest values of total capsaicinoids and therefore the highest level of pungency - more than 674 thousands SHU (Fig. 1, C).

Previous studies indicated that the capsaicinrich extracts, which contain both aminogroups of capsaicin along with other candidate phenolic compounds, played a reducing and controlling role during the formation of Ag-NPs in the solutions of green C. annuum and C. frutescens fruits [20,21]. We also revealed a strong correlation between the content of these compounds and the antioxidative activity of extracts, produced by both extracting agents (Fig. 1, $D$ ). The antioxidant activity of the investigated extracts, measured with the DPPH method, ranged from $3 \%$ for acetone extract of cv. Teja (S-17) fruits to $27 \%$ for methanol extract of cv. Carolina Reaper.

Phytocemical screening of Capsicum sp. fruits confirmed the appropriateness of their use for the 

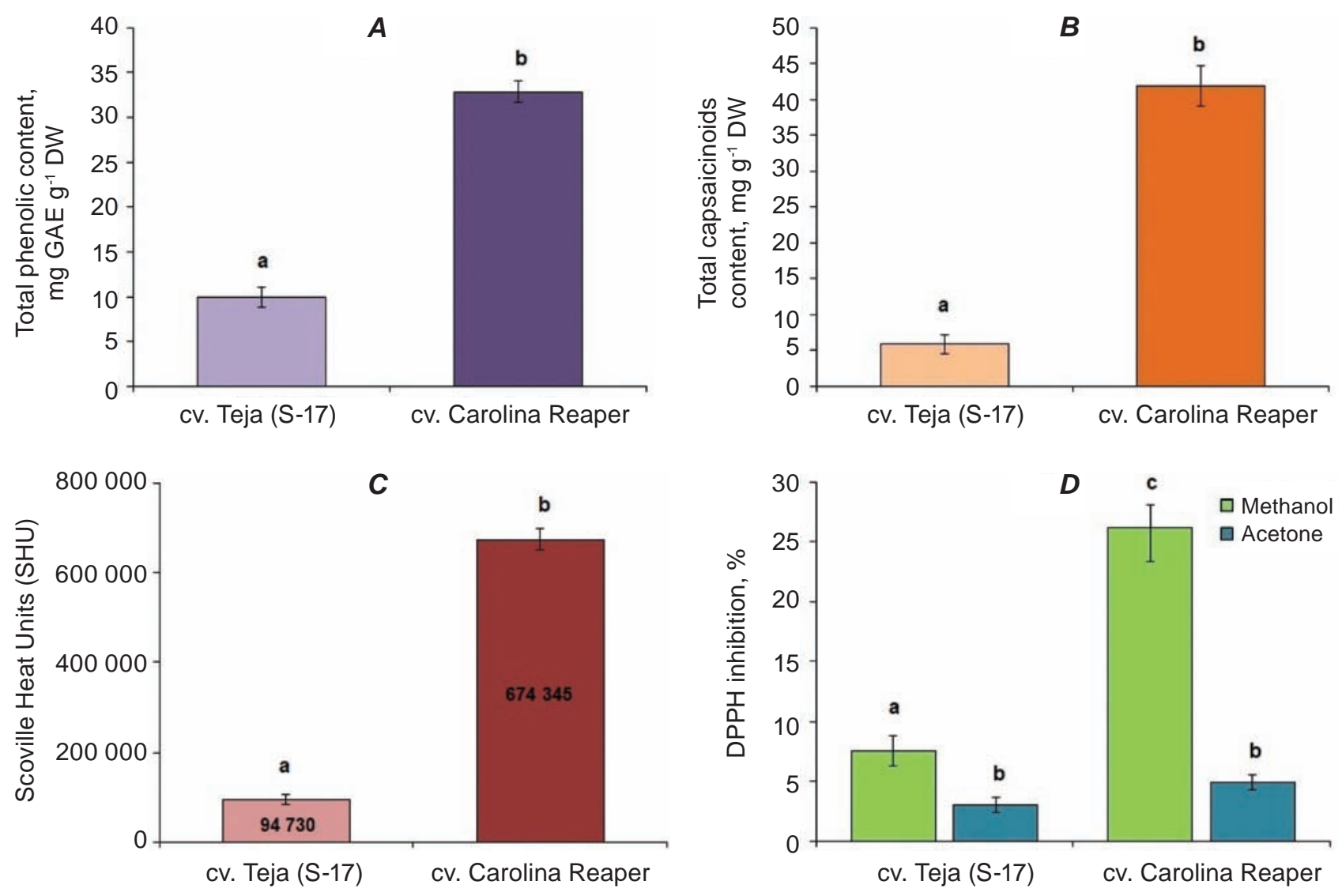

Fig. 1. Levels of secondary metabolites with reducing activity in extracts of dry pericarp tissues of Capsicum sp.: $\boldsymbol{A}$ - total phenolic compounds content in methanol extract, $\boldsymbol{B}$ - total capsaicinoidscontent in acetone extract, $\boldsymbol{C}$ - level of pungency of dry pericarp tissues of Capsicum sp. in Scoville Heat Units (SHU), D - antiradical activity of methanol and aceton extracts: means labelled by the same letters were not significantly different at $P<0.01$ according to the Duncan's multiple range test. Vertical bars indicate standard deviation $( \pm S D)$

Ag-NPs synthesis, since this fruit extract contains many secondary metabolites (phenolc compounds and capsaicinoids), which potentially act as sensible reducing and stabilizing agents of the $\mathrm{Ag}^{+}$.

The verification and confirmation of Ag-NPs production can be achieved through various approaches, including visual changing the color of a colorless silver nitrate solution to a brown suspension of silver nanocompounds. The change of color is a visible manifestation of the surface plasmon resonance (SPR) effect that is shown at inset to Fig. 2.

The ultraviolet-visible (UV-vis) spectrophotometry assays of prepared Ag-NPs solutions were captured after 2 hours of incubation under light exposure and were compared to $0.001 \mathrm{M}$ solution of silver nitrate and plant extracts spectra, while distilled water was used as a blank. As illustrated on Fig. 2, the absorbance peaks for biosynthesized Ag nano- particles were different and recorded as at $430 \mathrm{~nm}$ for Teja (S-17) Ag-NPs and at $450 \mathrm{~nm}$ for Carolina Reaper Ag-NPs. A sharp increase in the absorbance intensity in the region of 430-450 $\mathrm{nm}$ is explained by the excitation of SPR in Ag-NPs, which develops faster under illumination [22], and consistent with present investigations [23, 24, 25], assuming reduction of silver ions to silver nanoparticles. As SPR absorbance profile depends on the shape and size of biosynthesized nanoparticles, as well as on the presence of stabilizing components in reducing solutions (plant extracts) [26], we evaluated obtained SPR spectra bands. A flatter and wider peak of sample 5 (Carolina Reaper Ag-NPs) indicates a wider range of size distribution for biosynthesized Ag-NPs. The sharp characteristic peak in the sample 4 (Teja (S-17) Ag-NPs) is associated with increasing uniformity in shape and size of the synthesized nanoparticles. 


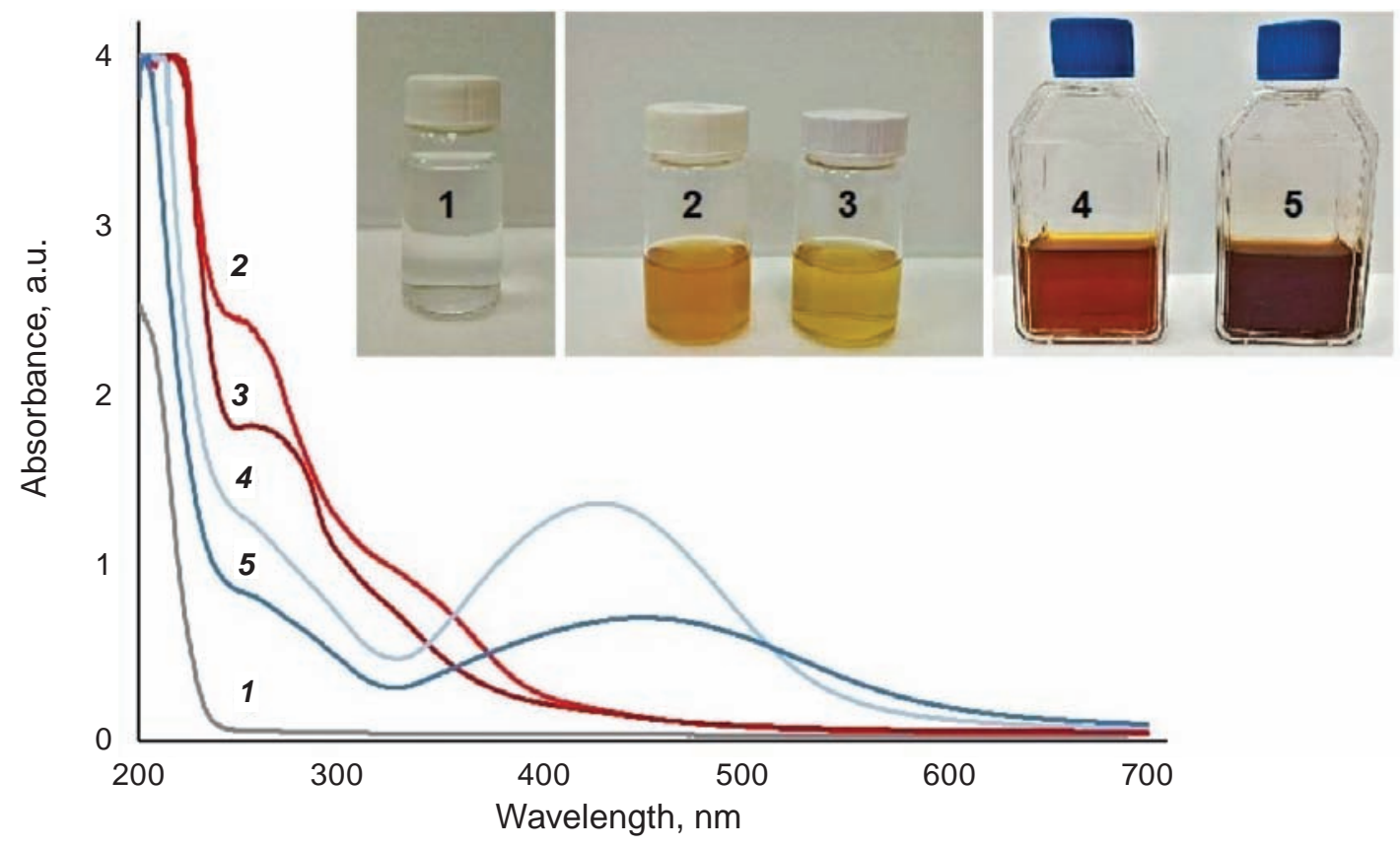

Fig. 2. UV-vis absorption spectra of experimental solutions: 1 - 0.001 M silver nitrate, 2 - extract of dry pericarp tissues of Capsicum sp. cv. Teja (S-17), 3 - extract of dry pericarp tissues of Capsicum sp. cv. Carolina Reaper, 4 - biosynthesised silver nanoparticles in the extract of dry pericarp tissues of Capsicum sp. cv. Teja (S-17), 5 - biosynthesised silver nanoparticles in the extract of dry pericarp tissues of Capsicum sp. cv. Carolina Reaper. The inset shows the color change of solutions - visible manifestation of the SPR effect

The morphology and size range of green synthesized Ag-NPs was evaluated by scanning electron microscopy. Analysis of SEM images (Fig. 3) showed that the biosynthesized Ag-NPs were welldispersed with a spherical shape.

Thus, the optical features of Ag-NPs nanoparticles are mostly influenced by the size distribution of nanoparticles [27], which correlates with UV-vis data. The morphometrical analysis of the obtained SEM images showed that the average size of biosynthesized nanoparticles varied from 13 to $22 \mathrm{~nm}$ for Teja (S-17) Ag-NPs and from 8 to $22 \mathrm{~nm}$ for Carolina Reaper Ag-NPs. A similar size distribution between 10 and $26 \mathrm{~nm}$ for small spherical biosynthesized nanoparticles, obtained after the use of the extracts from Calotropis procera flowers as reducing agents, was previously reported by Babu and Prabu [28].

The antimicrobial activity of biosynthesized Ag-NPs was assessed against pathogenic microbe Pseudomonas aeruginosa. This study was conducted using the following samples: $0.001 \mathrm{M} \mathrm{AgNO3} \mathrm{(1),}$ aqueous extract of Capsicum sp. cv. Teja (S-17) fruits (2), aqueous extract of Capsicum sp. cv. Carolina Reaper fruits (3), biosynthesised Ag-NPs in the extract of Capsicum sp. cv. Teja (S-17) (4), biosynthesised Ag-NPs in the extract of Capsicum sp. cv.
Carolina Reaper (5) and ceftriaxone as positive control (Fig. 4).

The choice of the microorganism was based on the fact that Pseudomonas aeruginosa is a rodshaped, aerobic, Gram-negative bacterium, allocable to the family Pseudomonadaceae - a common cause of community-acquired and nosocomial-acquired pneumonia. The development of resistant $P$. aeruginosa strains is increasing globally due to the overuse of antibiotics [29]. The wide-spread identification of multidrug-resistant $P$. aeruginosa in humans and live-stock animals has led to the World Health Organization to assess multidrug-resistant $P$. aeruginosa as global hazard for human health [30].

Antibacterial potential of aqueous extracts of Capsicum sp. and biosynthesized Ag-NPs samples was evaluated in terms of zone of inhibition of bacterial growth and compared with $0.001 \mathrm{M}$ solution of silver nitrate. The results of the antibacterial activities are represented in Table.

The measurements of growth inhibition zone showed the absence of statistically significant difference between $\mathrm{AgNO}_{3}$ and both biosynthesized Ag-NPs samples. Extracts of Capsicum sp. did not exhibit any antibacterial activity. 


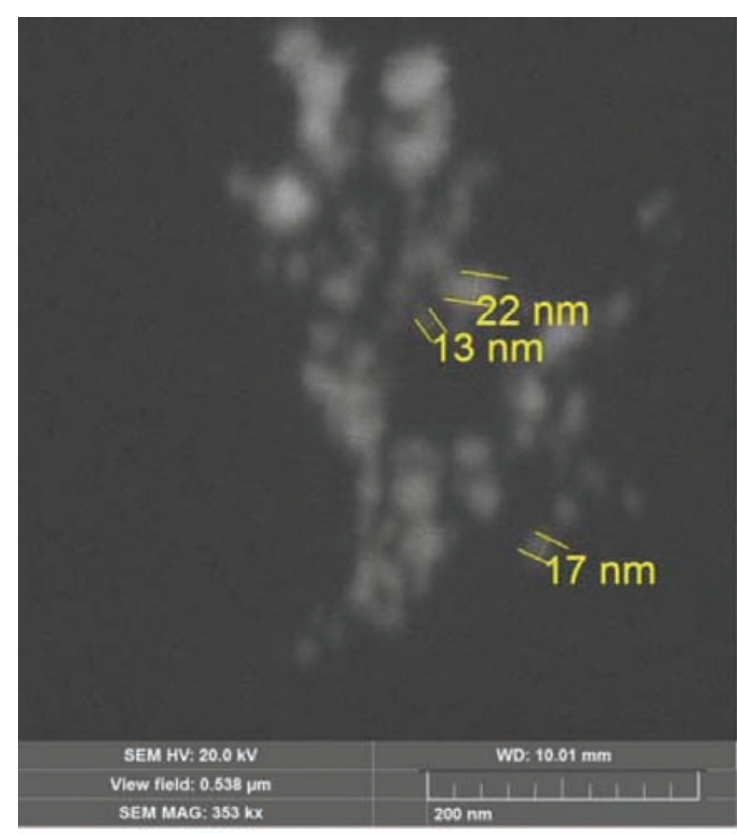

cv. Teja (S-17)

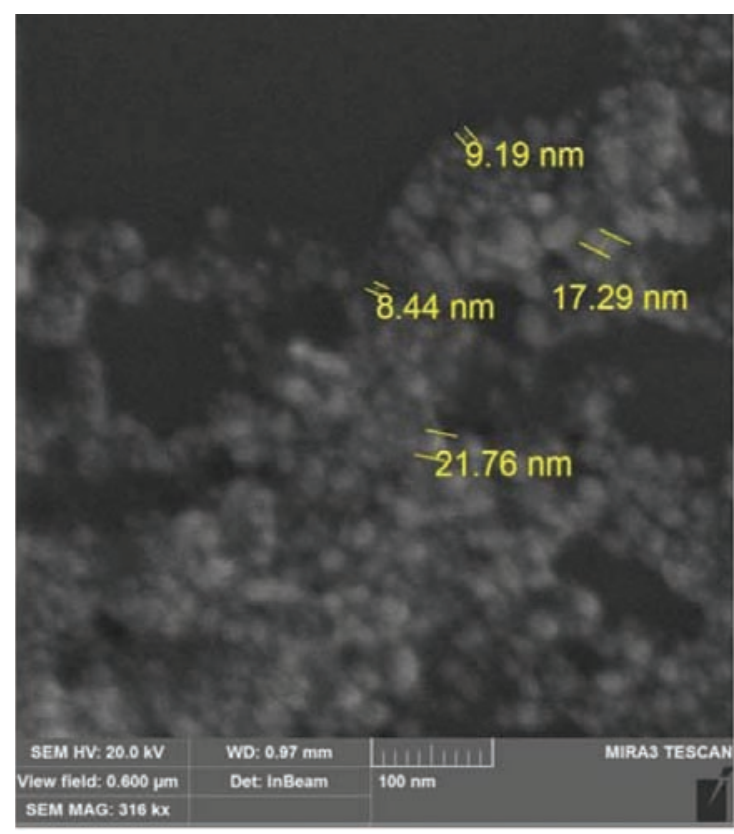

cv. Carolina Reaper

Fig. 3. Scanning electron microscopy micrograph images of silver nanoparticles biosynthesized using aqueous extracts of Capsicum sp. cv. Teja (S-17) and cv. Carolina Reaper

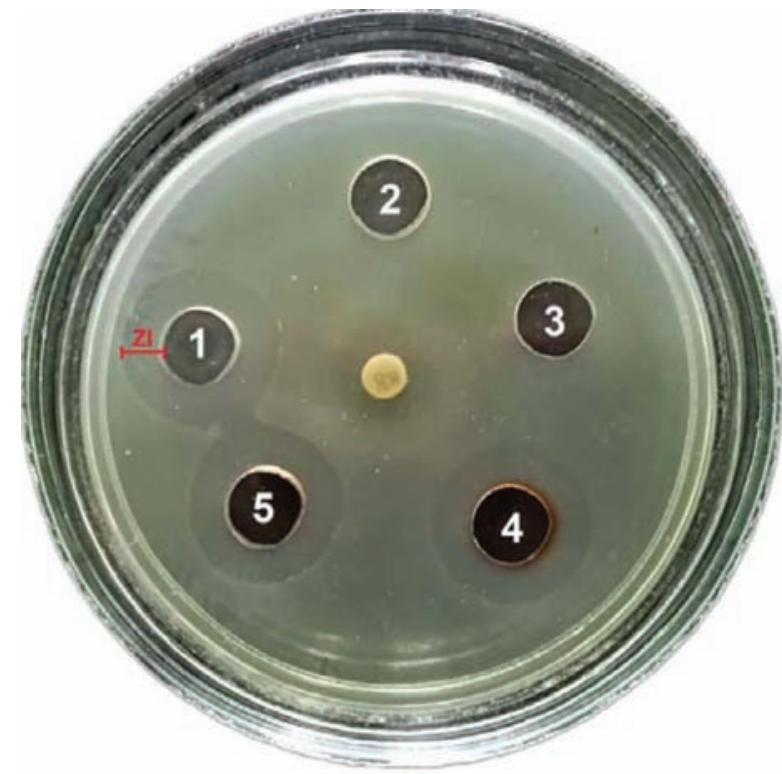

Fig. 4. Antimicrobial susceptibility agar diffusion method against $P$. aeruginosa: (ZI) - zone of inhibition of $0.001 M$ silver nitrate (1), extract of dry pericarp tissues of Capsicum sp. cv. Teja (S-17) (2), extract of dry pericarp tissues of Capsicum sp. $c v$. Carolina Reaper (3), biosynthesised silver nanoparticles in the extract of dry pericarp tissues of Capsicum sp. cv. Teja (S-17) (4), biosynthesised silver nanoparticles in the extract of dry pericarp tissues of Capsicum sp. cv. Carolina Reaper (5)
Ta b l e. Mean zone of inhibition (cm) of experimental solutions against $P$. aeruginosa: the mean and standard deviation (SD) reported for each type of experimental solution and with microbial strain were based on three biological replicates

\begin{tabular}{c|c|c}
\hline Variant & Experimental solution & $\begin{array}{c}\text { Mean width } \\
\text { of inhibition } \\
\text { zone, cm }\end{array}$ \\
\hline 1 & 0.001 M AgNO $_{3}$ \\
2 & $\begin{array}{c}\text { Extract of Capsicum } \\
\text { sp. cv. Teja (S-17) }\end{array}$ & $2.26 \pm 0.32$ \\
3 & $\begin{array}{c}\text { Extract of Capsicum } \\
\text { No. } \text { cv. Carolina Reaper }\end{array}$ & N/A \\
4 & Ag-NPs Teja (S-17) & $2.20 \pm 0.35$ \\
5 & Ag-NPs Carolina & \\
& Reaper & $2.23 \pm 0.34$ \\
\hline
\end{tabular}

* N/A - not available

Possible bactericidal mechanisms of Ag-NPs are still being investigated [31]. Several researches proposed that Ag-NPs may adhere to the surface of the cell wall and membrane of the bacterial cell, inhinit various enzymes within its cytoplasm, increase the production of reactive oxygen species and cause direct and indirect DNA damage [32, 33]. Deep in- 
vestigation of mechanisms underlying the Ag-NPs action would help in the development of safe nanomaterials for nanotechnology-based consumer products without harmful side effects [34].

Conclusions. We found that extracts from both of the analyzed hot chili peppers (Capsicum sp. cv. Teja (S-17) and cv. Carolina Reaper) showed significant antioxidant activity, combined with high levels of total phenolic and capsacinoid contents. Despite the difference in amount of accumulated reducing compounds, both extract were shown to produce Ag-NPs with comparable efficiency and antimicrobial activity against Pseudomonas aeruginosa. Therefore, aqueos extracts of hot chili peppers can be effectively used for green synthesis of biologically active silver nanoparticles.

Conflict of interest. Authors have completed the Unified Conflicts of Interest form at http://ukrbiochemjournal.org/wp-content/uploads/2018/12/ coi_disclosure.pdf and declare no conflict of interest.

Funding. This research did not receive any specific grant from funding agencies in the public, commercial, or not-for-profit sectors. VD thanks the National Research Foundation of Ukraine for support (project no. 2020.02/0204, 2020-2022).

\section{ЗЕЛЕНИЙ СИНТЕЗ \\ НАНОЧАСТИНОК СРІБЛА ЗА ДОПОМОГОЮ ВОДНОГО ЕКСТРАКТУ ПЛОДІВ ГОСТРОГО ПЕРЦЮ ЧИЛІ ТА ЇХНЯ АНТИБАКТЕРІАЛЬНА АКТИВНІСТЬ ПРОТИ PSEUDOMONAS AERUGINOSA}

\author{
О. С. Смірнов ${ }^{1,2}$, В. С. Калиновський \\ Ю. М. Юмина 1 , П. П. Зелена 1 , М. А. Скорик ${ }^{3}$, \\ В. М. Джаган ${ }^{4}$, Н. Ю. Таран
}

$$
\begin{gathered}
{ }^{1} \text { ННЦ «Інститут біології та медицини», } \\
\text { Київський національний університет } \\
\text { імені Тараса Шевченка, Україна; } \\
\text { ²Інститут фізіологї рослин і } \\
\text { генетики, НАН України, Київ; } \\
\text { НАнститут металофізики ім. Г. В. Курдюмова } \\
\text { НАН України, Київ; } \\
\text { }{ }^{4} \text { Інститут фізики напівпровідників імені } \\
\text { В. С. Лашкарьова НАН України, Київ; } \\
\text { е-таil: plantaphys@gmail.com }
\end{gathered}
$$

Зелений синтез наночастинок із використанням водних екстрактів рослин має перевагу у порівнянні $з$ іншими методами не тільки че- рез екологічно сприятливу природу рослин, а i тому що синтез є економічно ефективним. У роботі описано біосинтез наночастинок срібла (Ag HЧ) з використанням водного екстракту сухих перикарпів гострого перцю чилі (Capsicum sp. сортів Теја (S-17) та Carolina Reaper) 3 різним ступенем гостроти та антибактеріальної дії на стійку до антибіотиків Pseudomonas aeruginosa. Фітохімічний скринінг тканин перикарпів виявив велику різницю у вмісті фенольних сполук та капсаїциноїдів як потенційних відновлювальних агентів, що корелювало із загальною антирадикальною активністю, проаналізованою за відновленням DPPH радикалів. Біосинтезовані $\mathrm{Ag}$ НЧ було охарактеризовано за допомогою УФ-видимої спектрофотометрії і сканувальної електронної мікроскопії (SEM). Показано, що середній розмір наночастинок в обох зразках був менше 25 нм. Вихідна концентрація обох зразків Ag НЧ призводила до інгібування росту P. aeruginosa з однаковою ефективністю.

К л ючов і слова: зелений синтез, наночастинки Ag, Capsicum sp., антибактеріальна активність.

\section{References}

1. Stoica AE, Chircov C, Grumezescu AM. Nanomaterials for Wound Dressings: An Up-toDate Overview. Molecules. 2020; 25(11): 2699.

2. Salomoni R, Léo P, Montemor AF, Rinaldi BG, Rodrigues MFA. Antibacterial effect of silver nanoparticles in Pseudomonas aeruginosa. Nanotechnol Sci Appl. 2017; 10: 115-121.

3. Lee SH, Jun BH. Silver Nanoparticles: Synthesis and Application for Nanomedicine. Int $\mathrm{J} \mathrm{Mol}$ Sci. 2019; 20(4): 865.

4. de Jesús Ruíz-Baltazar Á., Reyes-López SY, Larrañaga D, Estévez M, Pérez R. Green synthesis of silver nanoparticles using a Melissa officinalis leaf extract with antibacterial properties. Results Phys. 2017; 7: 2639-2643.

5. Borovaya M, Naumenko A, Horiunova I, Plokhovska S, Blume Y, Yemets A. "Green" synthesis of $\operatorname{Ag}_{2} \mathrm{~S}$ nanoparticles, study of their properties and bioimaging applications. Appl Nanosci. 2020; 10(12): 4931-4940.

6. Prasher P, Singh M, Mudila H. Silver nanoparticles as antimicrobial therapeutics: current perspectives and future challenges. 3 Biotech. 2018; 8(10): 411. 
7. Babenko LM, Smirnov OE, Romanenko KO, Trunova OK, Kosakivska IV. Phenolic compounds in plants: functions and biogenesis. Ukr Biochem J. 2019; 91(3): 5-18.

8. Hamed M, Kalita D, Bartolo ME, Jayanty SS. Capsaicinoids, Polyphenols and Antioxidant Activities of Capsicum annuum: Comparative Study of the Effect of Ripening Stage and Cooking Methods. Antioxidants (Basel). 2019; 8(9): 364.

9. Burkowska-But A, Sionkowski G, Walczak M. Influence of stabilizers on the antimicrobial properties of silver nanoparticles introduced into natural water. $J$ Environ Sci (China). 2014; 26(3): 542-549.

10. Salari S, Esmaeilzadeh Bahabadi S, SamzadehKermani A, Yosefzaei F. In-vitro Evaluation of Antioxidant and Antibacterial Potential of GreenSynthesized Silver Nanoparticles Using Prosopis farcta Fruit Extract. Iran J Pharm Res. 2019; 18(1): 430-455.

11. Myint KZ, Yu Q, Xia Y, Qing J, Zhu S, Fang Y, Shen J. Bioavailability and antioxidant activity of nanotechnology-based botanic antioxidants. $J$ Food Sci. 2021; 86(2): 284-292.

12. Smirnov OE, Kosyan AM, Pryimak YuV, Kosyk OI, Taran NYu. Organo-specific accumulation of phenolic compounds in a buckwheat seedlings under aluminium-acid stress. Ukr Biochem J. 2021; 93(1): 75-81.

13. Ryu WK, Kim HW, Kim GD, Rhee HI. Rapid determination of capsaicinoids by colorimetric method. J Food Drug Anal. 2017; 25(4): 798-803.

14. Armstrong JM. The molar extinction coefficient of 2,6-dichlororophenol indophenol. Biochim Biophys Acta. 1964; 86: 194-197.

15. Rahman MM, Islam MB, Biswas M, Khurshid Alam AHM. In vitro antioxidant and free radical scavenging activity of different parts of Tabebuia pallida growing in Bangladesh. BMC Res Notes. 2015; 8: 621.

16. Reda M, Ashames A, Edis Z, Bloukh S, Bhandare R, Abu Sara H. Green Synthesis of Potent Antimicrobial Silver Nanoparticles Using Different Plant Extracts and Their Mixtures. Processes. 2019; 7(8): 510.

17. Fiebelkorn KR, Crawford SA, McElmeel ML, Jorgensen JH. Practical disk diffusion method for detection of inducible clindamycin resistance in Staphylococcus aureus and coagulase-negative staphylococci. J Clin Microbiol. 2003; 41(10): 4740-4744.

18. Chinn MS, Sharma-Shivappa RR, Cotter JL. Solvent extraction and quantification of capsaicinoids from Capsicum chinense. Food Bioprod Process. 2011;89(4):340-345.

19. Dailey A, Vuong QV. Effect of extraction solvents on recovery of bioactive compounds and antioxidant properties from macadamia (Macadamia tetraphylla) skin waste. Cogent Food Agric. 2015; 1(1): 1115646.

20. Oseguera-Galindo DO, Oceguera-Contreras E, Pozas-Zepeda D. Silver nanoparticles synthesis using biomolecules of habanero pepper (Capsicum chinense Jacq.) as a reducing agent. J Nanophotonics. 2020; 14(3): 036012.

21. Shankar T, Karthiga P, Swarnalatha K, Rajkumar K. Green synthesis of silver nanoparticles using Capsicum frutescence and its intensified activity against E. coli. Res Effic Technol. 2017; 3(3): 303-308.

22. Kumar AS, Madhu G, John E, Kuttinarayanan SV, Nair SK. Optical and antimicrobial properties of silver nanoparticles synthesized via green route using honey. Green Process Synth. 2020; 9(1): 268-274.

23. Kharabi Masooleh A, Ahmadikhah A, Saidi A. Green synthesis of stable silver nanoparticles by the main reduction component of green tea (Camellia sinensis L.). IET Nanobiotechnol. 2019; 13(2): 183-188.

24. Hamouda RA, Hussein MH, Abo-elmagd RA, Bawazir SS. Synthesis and biological characterization of silver nanoparticles derived from the cyanobacterium Oscillatoria limnetica. Sci Rep. 2019; 9(1): 13071.

25. Varghese Alex K, Tamil Pavai P, Rugmini R, Shiva Prasad M, Kamakshi K, Sekhar KC. Green Synthesized Ag Nanoparticles for BioSensing and Photocatalytic Applications. ACS Omega. 2020; 5(22): 13123-13129.

26. Chung IM, Park I, Seung-Hyun K, Thiruvengadam M, Rajakumar G. Plant-Mediated Synthesis of Silver Nanoparticles: Their Characteristic Properties and Therapeutic Applications. Nanoscale Res Lett. 2016; 11(1): 40.

27. Maddinedi SB, Mandal BK, Maddili SK. Biofabrication of size controllable silver nanoparticles - A green approach. $J$ Photochem Photobiol B. 2017; 167: 236-241. 
28. Babu SA. Prabu HG. Synthesis of AgNPs Using the Extract of Calotropis Procera Flower at Room Temperature. Mater Lett. 2011; 65(11): 1675-1677.

29. Yayan J, Ghebremedhin B, Rasche K. Antibiotic Resistance of Pseudomonas aeruginosa in Pneumonia at a Single University Hospital Center in Germany over a 10-Year Period. PLoS One. 2015; 10(10): e0139836.

30. Heimesaat MM, Escher U, Grunau A, Kühl AA, Bereswill S. Multidrug-Resistant Pseudomonas aeruginosa Accelerate Intestinal, Extra-Intestinal, and Systemic Inflammatory Responses in Human Microbiota-Associated Mice With Subacute Ileitis. Front Immunol. 2019; 10: 49.

31. Javan Bakht Dalir S, Djahaniani H, Nabati F, Hekmati M. Characterization and the evaluation of antimicrobial activities of silver nanoparticles biosynthesized from Carya illinoinensis leaf extract. Heliyon. 2020; 6(3): e03624.

32. Kvitek L, Panacek A, Soukupova J, Koláŕ M, Večeřová R, Prucek R, Holecová AM, Zbořil R. Effect of Surfactants and Polymers on Stability and Antibacterial Activity of Silver Nanoparticles (NPs). J Phys Chem C. 2008; 112: 5825-5834.

33. Tamboli DP, Lee DS. Mechanistic antimicrobial approach of extracellularly synthesized silver nanoparticles against gram positive and gram negative bacteria. J Hazard Mater. 2013; 260: 878-884.

34. Zhang XF, Shen W, Gurunathan S. Silver Nanoparticle-Mediated Cellular Responses in Various Cell Lines: An in Vitro Model. Int J Mol Sci. 2016; 17(10): 1603. 